ZOOLOGIA 27 (6): 945-955, December, 2010

doi: $10.1590 /$ S1984-46702010000600016

\title{
Seasonal variation of epiphytic hydroids (Cnidaria: Hydrozoa) associated to a subtropical Sargassum cymosum (Phaeophyta: Fucales) bed
}

\author{
Amanda Ferreira Cunhaํ \& Giuliano Buzá Jacobucci²
}

\author{
1 Programa de Pós-Graduação em Zoologia, Instituto de Biociências, Universidade de São Paulo. Rua do Matão, \\ Travessa 14, 101, Cidade Universitária, 05508-900 São Paulo, SP, Brazil. E-mail: afcunha@ib.usp.br \\ 2 Instituto de Biologia, Universidade Federal de Uberlândia. Rua Ceará, Campus Umuarama, 38402-400 Uberlândia, \\ MG, Brazil. E-mail: jacobucci@inbio.ufu.br
}

\begin{abstract}
Hydroids are broadly reported in epiphytic associations from different localities showing marked seasonal cycles. Studies have shown that the factors behind these seasonal differences in hydroid richness and abundance may vary significantly according to the area of study. Seasonal differences in epiphytic hydroid cover and richness were evaluated in a Sargassum cymosum C. Agardh bed from Lázaro beach, at Ubatuba, Brazil. Significant seasonal differences were found in total hydroid cover, but not in species richness. Hydroid cover increased from March (early fall) to February (summer). Most of this pattern was caused by two of the most abundant species: Aglaophenia latecarinata Allman, 1877 and Orthopyxis sargassicola (Nutting, 1915). Hydroid richness seems to be related to S. cymosum size but not directly to its biomass. The seasonal differences in hydroid richness and algal cover are shown to be similar to other works in the study region and in the Mediterranean. Seasonal recruitment of hydroid species larvae may be responsible for their seasonal differences in algal cover, although other factors such as grazing activity of gammarid amphipods on S. cymosum must be taken into account.
\end{abstract}

KEY WORDS. Epibionts; hydroid cover; hydrozoans.

Hydroids are benthic sessile organisms very common in marine shallow water communities, in which they play a significant role of energy transfer from the plankton to the benthos (Gili \& Hughes 1995, Gili et al. 1998). They occur in a variety of natural and artificial substrates (CALDER 1991a, Genzano \& RodRIGUEz 1998), and are broadly reported in epiphytic associations (Nishinira 1971, Boero et al. 1985, Fraschetti et al. 2002, see OliveIra \& MARQues 2007 for more references). Algal substrate is particularly important in offering continuous available space for attachment (HAYWARD 1980, SEED \& O'CONNOR 1981), especially for opportunistic space competitors and species with short life spans, such as shallow water hydroids (GiLI et al. 1989).

Studies have shown that the diversity of hydroids is strongly influenced by seasonality, but the factors responsible for their seasonal cycles varies according to the area of study (Coma et al. 2000, Bavestrello et al. 2006). In cold temperate waters, the occurrence of winter dormancy among hydroid species seems to be caused by variations in water temperature and food availability (Hughes 1986). These factors as well seem to be responsible for the summer dormancy shown by some warm water species of the Mediterranean (Coma \& Ribes 2003), although water movement and light intensity may also affect the occurrence of some species in this region (AriLlo et al. 1989, FAUCCI \& Boero 2000). In the tropical areas, hydroids seasonal cycles are mainly influenced by the different conditions of nutrient availability and water turbidity caused by the alternation of wet and dry seasons, since temperature and solar radiation are relatively constant throughout the year (BoERo 1994, Camillo et al. 2008).

Temporal variations in the composition and abundance of epiphytic hydroids are common and they can also be caused by biotic factors in a local scale, such as the structural complexity of the algae (FraschetTI et al. 2006), senescence of the algal substrate and competition for substrate with epiphytic algae and other species of hydroids (Boero \& Fresi 1986, LLOBET et al. 1991). Interspecific competition can alter patterns of distribution of hydroids throughout time in epiphytic environments (KaTo et al. 1961, 1962a, b, 1969), especially species cover (e.g. García-Rubies 1992).

Several studies have dealt with the ecology of hydroids occurring on Sargassum throughout the world. In Japan, Nishinira $(1965,1968 c, 1971)$ and KaTo et al. (1961) investigated the ecology of epiphytic hydroids from various species of Sargassum, specially related to larval settlement and distribution patterns on the algae. Ryland (1974), Niermann (1986) and CALDER (1995) evaluated the abundance and distribution pattern of colonial epifauna associated with Sargassum in the North Atlantic. In Brazil there are many studies of hydroids occurring on Sargassum (e.g. Migotto 1996, Oliveira \& Marques 2007), but few of them have discussed hydroid ecology (e.g. 
Haddad \& Chiaverini 2000). In this sense, this study aims to evaluate the possible influence of season and algal characteristics on epiphytic hydroid cover and richness in a subtropical Sargassum cymosum C. Agardh bed.

\section{MATERIAL AND METHODS}

The sampling was carried out at Lázaro beach, located at Fortaleza inlet $\left(23^{\circ} 30^{\prime} \mathrm{S}, 45^{\circ} 08^{\prime} \mathrm{W}\right)$, in the municipality of Ubatuba, northeastern coast of the state of São Paulo, Brazil. This area presents large and continuous macroalgal beds that extend from the infralittoral fringe to approximately $4 \mathrm{~m}$ deep, and is moderately sheltered from wave action (JACOBUCCI \& LeiTE 2002). Sargassum cymosum is dominant in the area but other species of algae such as Dictyopteris delicatula Lamouroux may be found in lower abundances (Széchy \& Paula 1997).

Negreiros-Fransozo et al. (1991) registered higher values of maximum rainfall during March and lower levels during August for the Fortaleza inlet, with mean annual values of water temperature, dissolved oxygen and salinity of $23.5^{\circ} \mathrm{C}, 5.46 \mathrm{mg} /$ $\mathrm{L}$ and $34.4 \%$, respectively. In this same region, mean values of $S$. cymosum biomass and length were shown to be higher during spring and lower during summer and autumn by PAULA \& Oliveira-Filho (1980). These authors observed the presence of young and mature plants during the entire year, showing their primary and secondary axis in various stages of development, from initial differentiation to fertile or in senescence.

To evaluate seasonal variation in richness and abundance of epiphytic hydroids associated with $S$. cymosum, sampling was carried out in March, July and December 2007, and February 2008. In each sampling date, 20 algal fronds of $S$. cymosum were randomly collected by snorkeling, excepting July when 13 fronds were collected, due to logistical problems. The fronds were scraped off with a spatula and wrapped in cloth bags. The hydroids on S. cymosum were anesthetized immersing the fronds in a $7.5 \% \mathrm{MgCl}_{2} 6 \mathrm{H}_{2} \mathrm{O}$ solution for approximately two minutes, as described by Oliveira et al. (2006).

To measure hydroid cover, each frond was placed between two $30 \times 30 \mathrm{~cm}$ glass plates, marked with square subdivisions of $10 \times 10 \mathrm{~mm}$ (Fig. 1). When necessary the fronds were cut into fragments before being placed between the glass plates to avoid any overlap of the thallus. The measure of hydroid cover was done counting the subdivisions in which the algal fronds were present, and those in which hydroids were present (considering both sides of the plates). The number of subdivisions occupied by the fronds was used as a measure of the size of the fronds. Hydroid cover was calculated as the ratio between the number of subdivisions occupied by hydroids and the number of subdivisions occupied by the fronds. In this way, a proportion value was obtained, and then transformed into the percentage values of hydroid cover, for each frond and sampling period. After measuring hydroid cover, the fronds were dried pressing them between paper towels at room temperature for $48 \mathrm{~h}$ and then weighted to obtain their dry biomass.

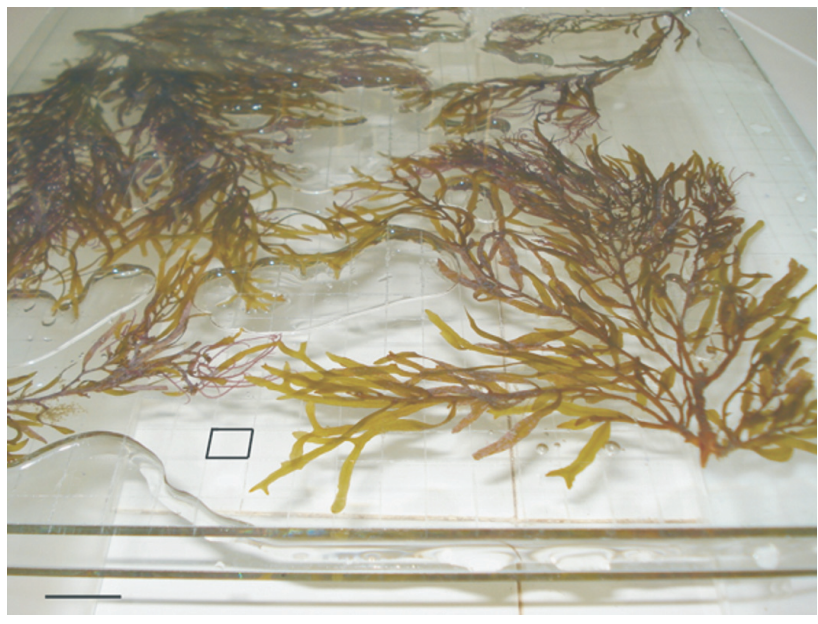

Figure 1. Sargassum cymosum fronds placed between two glass plates for analysis of hydroid cover. A square subdivision is highlighted with a black line. Scale: $2 \mathrm{~cm}$.

Hydroid species were identified with the help of specific literature (CAlder 1991b, Cornelius 1995a, b, Migotto 1996). Hydroid species frequency of occurrence, that is, the percentage of fronds in which each hydroid species was present, was calculated as the ratio between the number of fronds occupied by each hydroid species and the total number of fronds collected in each sampling period.

The data were compared among sampling periods through one way ANOVA followed by post hoc Tukey test, for significant differences. To infer possible relations of hydroid cover and richness with algae frond size and biomass we tested the association of these variables using Pearson correlation test. When necessary, the data were arcsine and $\log (\mathrm{x}+1)$ transformed to meet the assumptions of the tests ( $Z_{\mathrm{AR}}$ 1996).

In the dry biomass comparison among sampling periods, the relation of the samples from July and February with the other months was not clear. The same happened with the samples of species cover from July. That may happen when the multiple comparison test is not able to determine from which population these samples came from (ZAR 1996), even though the analysis of variance stated that they were different. In this sense, the comparisons of these variables were done only among those months which did not present any conflicts when the results of the multiple comparison test were interpreted.

\section{RESULTS}

We found 16 species of hydroids on S. cymosum fronds, from which 13 were Leptothecata and three Anthoathecata (Tab. I, Figs 2-17). In two cases it was not possible to identify the specimens to the species level since they were damaged and occurred in very low abundance. Hydroids occurred in all the fronds sampled during the study. Hydroid cover on $S$. 

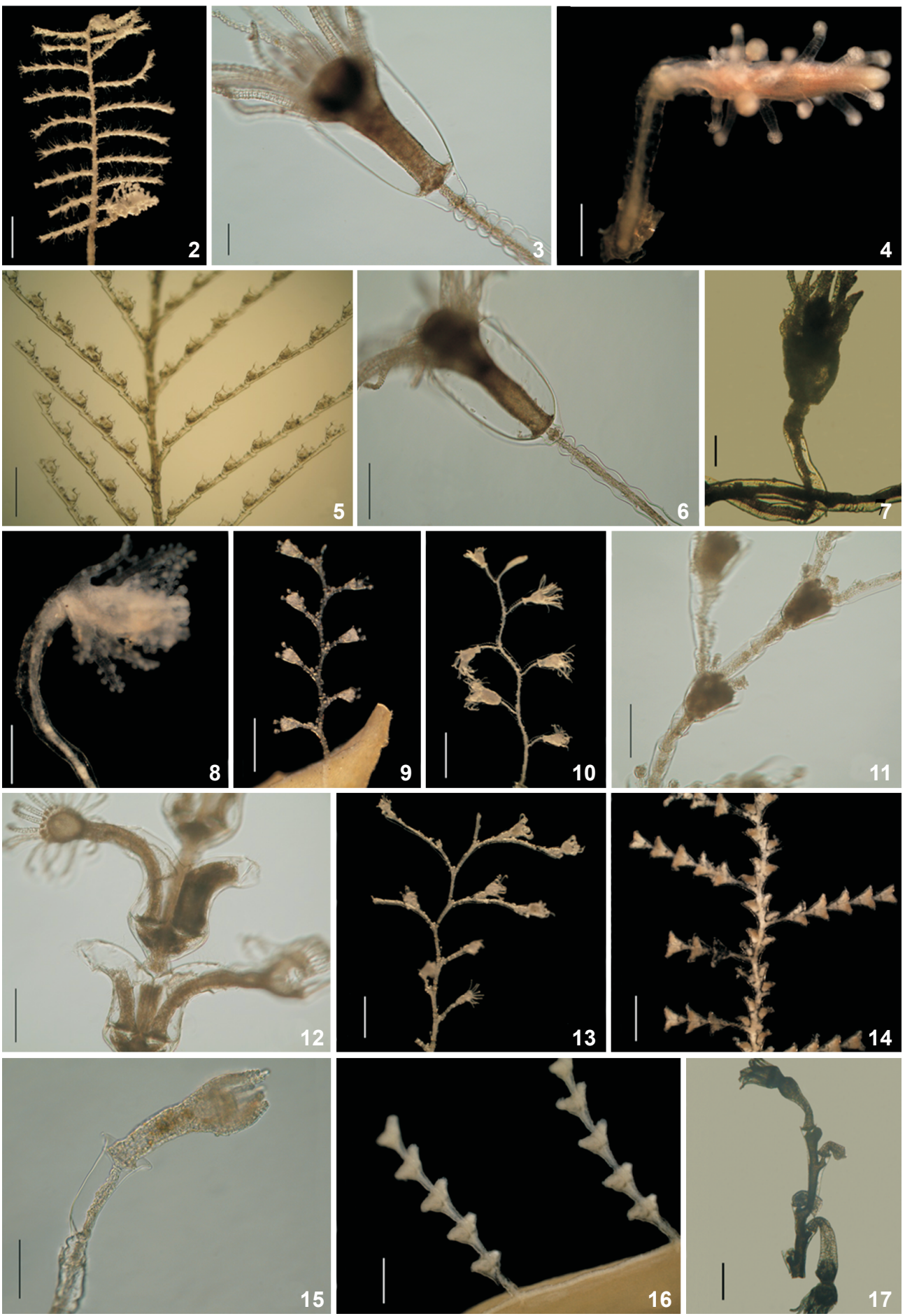

Figures 2-17. Species of hydroids found during analysis: (2) Aglaophenia latecarinata; (3) Clytia gracilis; (4) Coryne pusilla; (5) Dentitheca bidentata; (6) Orthopyxis sargassicola; (7) Eudendriidae sp1; (8) Cladocoryne floccosa; (9) Monotheca margaretta; (10) Obelia dichotoma; (11) Halopteris diaphana; (12) Dynamena disticha; (13) Plumularia strictocarpa; (14) Sertularia marginata; (15) Halecium tenellum; (16) Sertularia turbinata; (17) Haleciidae sp. 1. Scales: (2) $1 \mathrm{~mm},(3,6,7,11,12) 200 \mu \mathrm{m},(4) 300 \mu \mathrm{m},(5,8,9,13) 400 \mu \mathrm{m},(10,14,16) 700$ $\mu \mathrm{m},(15) 100 \mu \mathrm{m},(17) 250 \mu \mathrm{m}$. 
cymosum fronds varied among sampling periods $\left(\mathrm{F}_{3}=14.14, \mathrm{p}\right.$ $<0.05)$, with higher cover values on the fronds collected in February (Fig. 18).

Hydroid richness was not different among sampling periods $\left(\mathrm{F}_{3}=1.95, \mathrm{p}>0.05\right)$, with a mean value of three to four species per sampling period (Fig. 19). The highest number of hydroid species occurring on the same frond was seven, and few fronds (approximately 5\%) presented only one species. The size of the fronds, as well, was not different among sampling periods $\left(\mathrm{F}_{3}=2.01, \mathrm{p}>0.05\right.$, Fig. 20$)$, but was positively correlated with hydroids species richness $(r=0.29, \mathrm{p}<0.05$, Fig. 21). The dry biomass of the $S$. cymosum fronds was different among sampling periods $\left(\mathrm{F}_{3}=2.96, \mathrm{p}<0.05\right.$, Fig. 22) with higher values in December, but no correlation was detected among the fronds dry biomass and hydroids species richness $(r=0.19$, p > 0.05, Fig. 23).

Considering all the species found, five were present in all sampling periods while the others varied in their occurrences (Tab. I, Figs 24-27). Aglaophenia latecarinata Allman, 1877 presented the highest value of frond cover, with maximum of $71.4 \%$ of cover in one frond collected in February. Since many species occurred sporadically and presented low frond cover, we evaluated the seasonal difference of hydroid species cover only for the four species which occurred in at least $50 \%$ of the fronds collected in each month. Among these species, $A$. latecarinata and Orthopyxis sargassicola (Nutting, 1915) presented a higher percentage of cover in December and February (first species), and February (second species). Dynamena disticha (Bosc, 1802) and Sertularia turbinata (Lamouroux, 1816) had similar frond cover among sampling periods (Tab. II).

Table I. Frequency of occurrence (\%) of hydroid species in Lázaro beach, Ubatuba. Taxonomic list in accordance with Mıcoтto et al. (2002).

\begin{tabular}{|c|c|c|c|c|c|}
\hline Species & Code & March 2007 & July 2007 & December 2007 & February 2008 \\
\hline Number of Fronds & & 20 & 13 & 20 & 20 \\
\hline \multicolumn{6}{|l|}{ Anthoathecata } \\
\hline \multicolumn{6}{|l|}{ Cladocorynidae } \\
\hline Cladocoryne floccosa Rotch, 1871 & CF & - & 7.7 & 10.0 & 5.0 \\
\hline \multicolumn{6}{|l|}{ Eudendriidae } \\
\hline Eudendriidae sp. 1 & ED & 30.0 & 7.7 & 30.8 & - \\
\hline \multicolumn{6}{|l|}{ Corynidae } \\
\hline Coryne pusilla Gaertner, 1774 & $\mathrm{CP}$ & - & 7.7 & - & - \\
\hline \multicolumn{6}{|l|}{ Leptothecata } \\
\hline \multicolumn{6}{|l|}{ Aglaopheniidae } \\
\hline Aglaophenia latecarinata Allman, 1877 & $\mathrm{AL}$ & 85.0 & 92.3 & 90.0 & 100.0 \\
\hline \multicolumn{6}{|l|}{ Haleciidae } \\
\hline Haleciidae sp. 1 & $\mathrm{HA}$ & - & - & - & 5.0 \\
\hline Halecium tenellum Hincks, 1861 & HT & - & 15.4 & - & - \\
\hline Halopterididae & & & & - & - \\
\hline Halopteris diaphana (Heller, 1868) & HD & 25.0 & - & - & - \\
\hline Plumulariidae & & & & - & \\
\hline Dentitheca bidentata (Jäderholm, 1920) & DB & - & 7.7 & - & 10.0 \\
\hline Monotheca margaretta Nutting, 1900 & MM & 15.0 & 46.2 & 20.0 & 15.0 \\
\hline Plumularia strictocarpa Pictet, 1893 & PS & 20.0 & 7.7 & - & 5.0 \\
\hline \multicolumn{6}{|l|}{ Sertulariidae } \\
\hline Dynamena disticha (Bosc, 1802) & DD & 85.0 & 84.6 & 70.0 & 65.0 \\
\hline Sertularia marginata (Kirchenpauer,1864) & SM & - & - & 5.0 & 5.0 \\
\hline Sertularia turbinata (Lamouroux, 1816) & ST & 80.0 & 84.6 & 65.0 & 70.0 \\
\hline \multicolumn{6}{|l|}{ Campanulariidae } \\
\hline Clytia gracilis (M. Sars, 1851) & CG & 10.0 & 15.4 & - & 25.0 \\
\hline Obelia dichotoma (Linnaeus, 1758) & OD & - & 15.4 & - & 10.0 \\
\hline Orthopyxis sargassicola (Nutting, 1915) & Os & 50.0 & 53.8 & 50.0 & 80.0 \\
\hline
\end{tabular}

ZOOLOGIA 27 (6): 945-955, December, 2010 

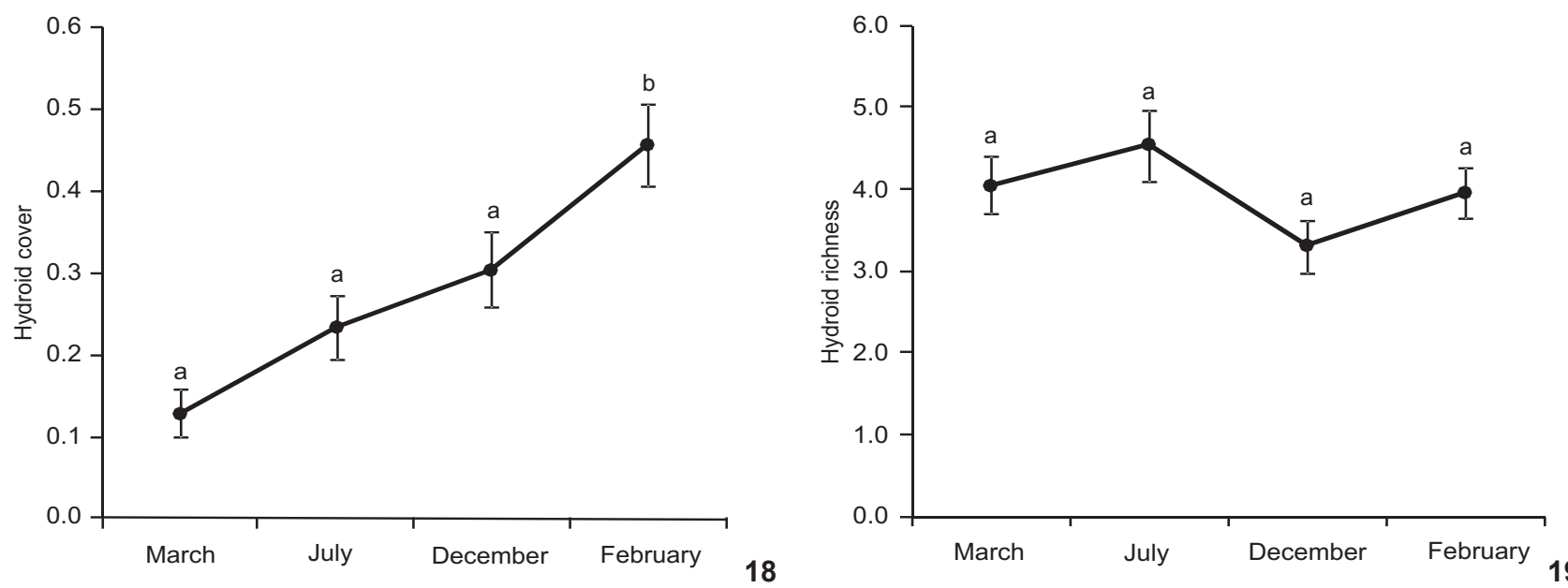

Figures 18-19. Hydroid algal cover and richness (mean values/frond \pm standard error) in Lázaro beach, Ubatuba. Cover was calculated as the ratio between the number of $1 \mathrm{~cm}^{2}$ subdivisions occupied by hydroids and the number of subdivisions occupied by the fronds (see text for details). Same letters indicate absence of significant differences.
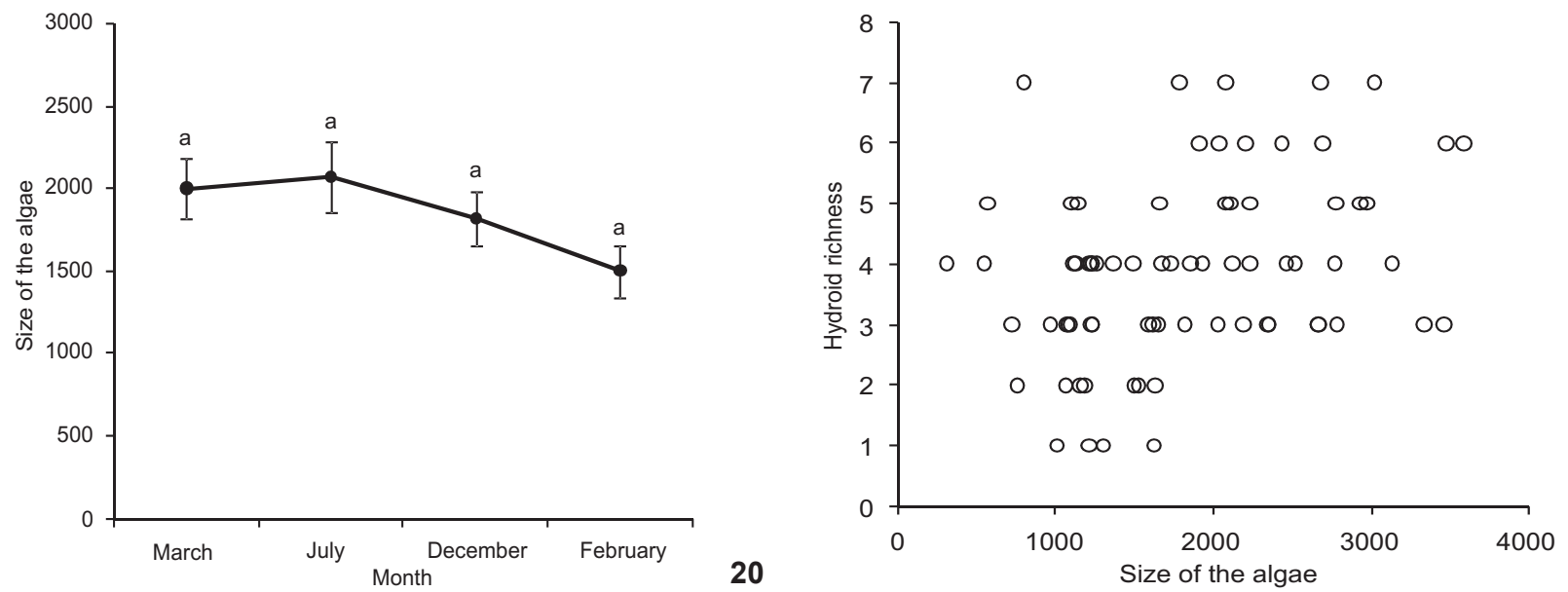

Figures 20-21. Sargassum cymosum frond size (number of $1 \mathrm{~cm}^{2}$ subdivisions occupied by the algae, see text for details) in Lázaro beach, Ubatuba, with its correspondent hydroid species richness. Same letters indicate absence of significant differences.

Table II. Mean values of hydroid cover ( \pm standard error), ANOVA and Tukey test results of the most frequent and abundant hydroid species at Lázaro beach (M: March, J: July, D: December, F: February). Cover was calculated as the ratio between the number of $1 \mathrm{~cm} 2$ subdivisions occupied by hydroids and the number of subdivisions occupied by the fronds (see text for details). Underlined letters indicate absence of significant differences.

\begin{tabular}{|c|c|c|c|c|c|c|}
\hline Species & $\begin{array}{c}\text { March } 2007 \\
(\mathrm{~N}=20)\end{array}$ & $\begin{array}{c}\text { July } 2007 \\
(\mathrm{~N}=13)\end{array}$ & $\begin{array}{c}\text { December } 2007 \\
(\mathrm{~N}=20)\end{array}$ & $\begin{array}{c}\text { February } 2008 \\
(\mathrm{~N}=20)\end{array}$ & ANOVA & Tukey \\
\hline Aglaophenia latecarinata & $0.040 \pm 0.010$ & $0.11 \pm 0.03$ & $0.180 \pm 0.030$ & $0.25 \pm 0.06$ & $F=7.82^{*}$ & $M \underline{D F}^{* *}$ \\
\hline Dynamena disticha & $0.060 \pm 0.020$ & $0.06 \pm 0.03$ & $0.080 \pm 0.030$ & $0.06 \pm 0.03$ & $F=0.11$ & MJDF \\
\hline Orthopyxis sargassicola & $0.002 \pm 0.001$ & $0.02 \pm 0.01$ & $0.003 \pm 0.001$ & $0.11 \pm 0.05$ & $\mathrm{~F}=3.94^{*}$ & $\mathrm{~F} \underline{M D}^{* *}$ \\
\hline Sertularia turbinata & $0.020 \pm 0.010$ & $0.02 \pm 0.01$ & $0.030 \pm 0.010$ & $0.03 \pm 0.01$ & $F=0.14$ & MJDF \\
\hline
\end{tabular}

${ }^{*} p<0.05$. ${ }^{* *}$ The relation between July and the other months is not clear by the multiple comparison test. 

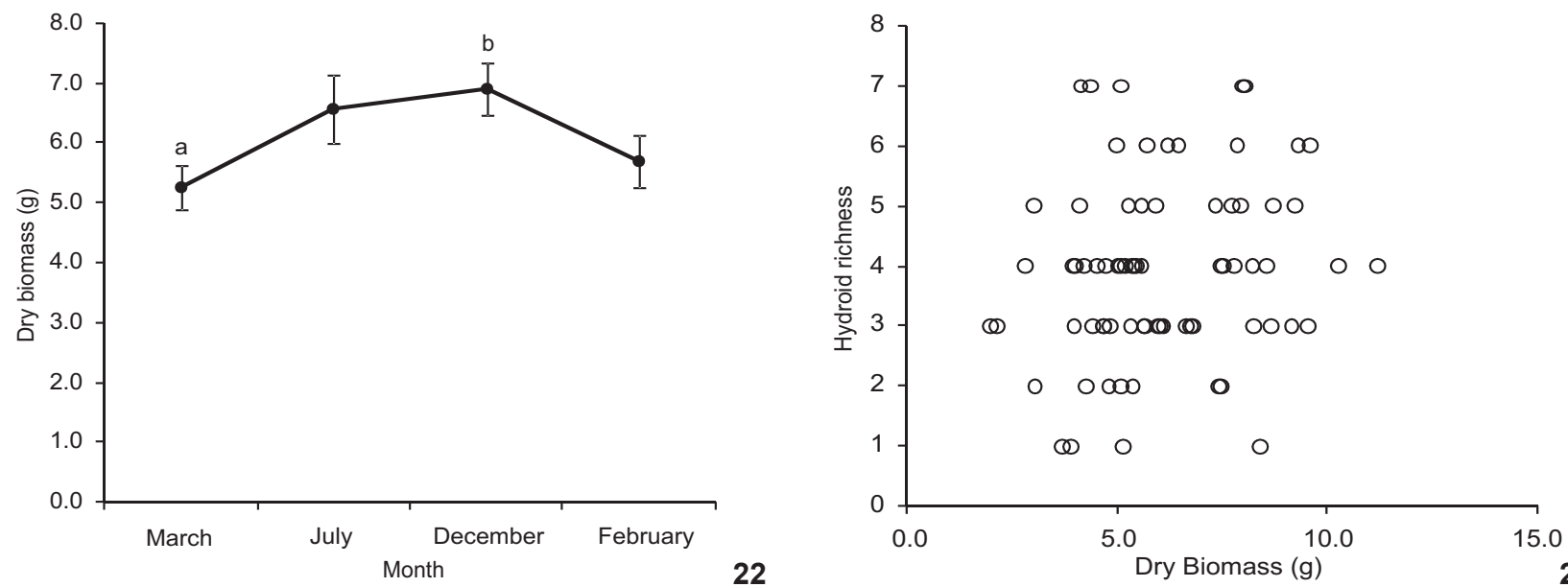

Figures 22-23. Sargassum cymosum dry biomass (mean values \pm standard error) in Lázaro beach, Ubatuba, with its correspondent hydroid species richness. Same letters indicate absence of significant differences. The relation between July and February with the other months is not clear by the multiple comparison test.

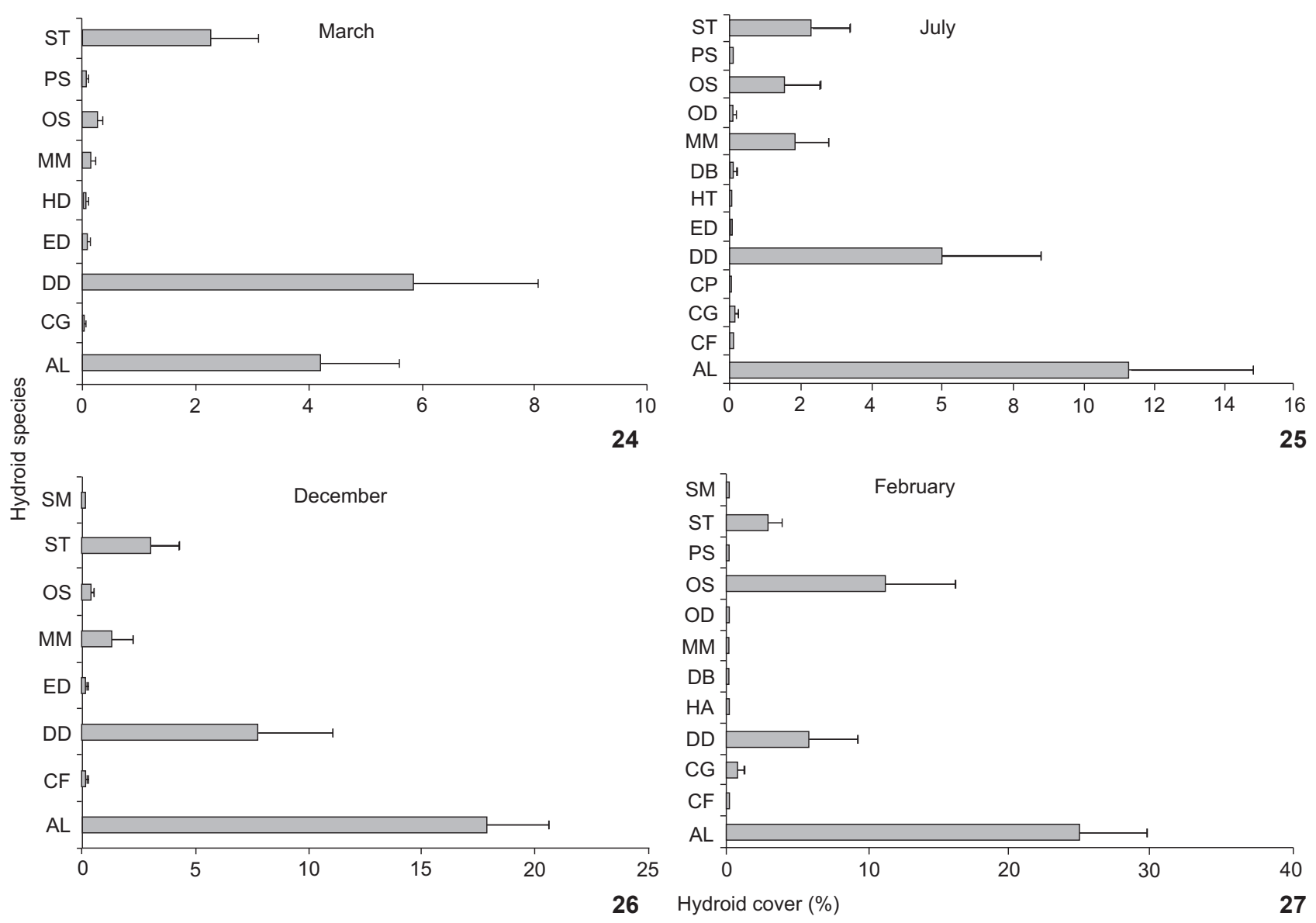

Figures 24-27. Percentages of hydroid species algal cover (mean values/frond \pm standard error) in the sampling periods in which they occurred. Cover was calculated as the ratio between the number of $1 \mathrm{~cm}^{2}$ subdivisions occupied by hydroids and the number of subdivisions occupied by the fronds (see text for details). Species codes are in accordance with table I. 


\section{DISCUSSION}

Hydroid cover in Lázaro beach showed lower levels during early autumn, winter and early summer (March, July and December, respectively) followed by an increase during late summer (February). Hydroid richness however, was constant, without seasonal variations. Epiphytic hydroid richness and abundance were also shown to be higher during summer at the Mediterranean region (Llobet et al. 1991, Fraschetti et al. 2002), although FAUCCI \& BOERO (2000) reported an increase in hydroid richness and abundance during the cold season at this same region. WATSON (1992) found differences in hydroid colonization level between two different sites, at southern and southwestern Australia, the first presenting maximum hydroid colonization during summer and the last during early winter. Also in Australia, Borowitzka et al. (1990) found a higher number of epiphytic organisms during summer. At the Atlantic coast of United States, CALDER (1990) found marked seasonal activity cycles of hydroid species, and the greatest number of species occurring during late spring.

The number of hydroid species (16) occurring on $S$. cymosum in Lázaro beach may be considered relatively high when compared to other studies of epiphytic hydroids on Sargassum. NishiniRa (1965) found 14 species on S. hemiphyllum (Turner) C. Agardh and 10 species on S. tortile C. Agardh from Japan, CaLder (1995) found 10 species on $S$. fluitans Boergesen and eight species on S. natans (Linnaeus) Gaillon from Bermuda, and HADDAD $\&$ Chiaverini (2000) found seven species on S. stenophylum Martius from Guaratuba, Brazil. Differences in hydroid richness among localities may be caused by the different algal substrate in which they occur. Studies have shown that hydroid species composition may even differ among algae species that occur at the same locality (e.g. WATSON 1992, FAUCCI \& BOERo 2000), and that is probably caused by variations in the life cycle of the host. It can influence the hydroid ability of colonization of different host parts and provide more or less available space for attachment during different periods of the year (BOROWITZKa et al. 1990, LLOBET et al. 1991, García-Rubies 1992).

The maximum species richness recorded for a single frond was similar to that recorded by CALDER (1995) on S. fluitans from Bermuda, although he did not find less than two species of hydroids occurring on the same frond. In the present study, approximately $5 \%$ of the fronds of $S$. cymosum presented only one hydroid species. Haddad \& Chiaverini (2000) found the majority of the $S$. stenophylum samples colonized by one species of hydroid, while O.M.P. Oliveira (pers. comm.) noticed a high frequency of $S$. cymosum fronds from the São Sebastião channel without any hydroid species. These authors believe that the occurrence of few or no species per algal frond seems to be a result of its size, considering that smaller fronds may offer less available space for attachment. This may be evidenced when the size of the fronds of Sargassum is compared. $S$. cymosum from Ubatuba present a maximum length of about
$30 \mathrm{~cm}$ (Paula \& Oliveira-Filho 1980) and S. stenophylum from Guaratuba $35 \mathrm{~cm}$ (HADDAD \& Chiaverini 2000), while $S$. fluitans and $S$. natans from Bermuda present a maximum length of about 100 and $50 \mathrm{~cm}$, respectively (LitTLer et al. 1989). The positive correlation between algal frond size and hydroid richness found in the present study reinforces the importance of available space for attachment to hydroid richness. This factor may explain the absence of differences in the number of species colonizing $S$. cymosum among sampling periods since no differences on the size of the fronds were detected among periods.

The structural complexity of the algae may also influence hydroid colonization and species richness, since more complex algae offers a higher number of microhabitats for attachment (FraschetTi et al. 2006, Ronowicz et al. 2008). Studies have shown that algal biomass may be a measure of its complexity, since higher values of biomass may be related to increased living space, food availability and protection from predators, favoring epiphytic species richness and abundance (Heck \& Wetstone 1977, Stoner 1980, Leite \& Turra 2003). Despite this, in this study $S$. cymosum biomass was not related to hydroid species richness. The dry biomass of $S$. cymosum fronds of Lázaro beach increased in December, but it was not followed by an increase in hydroid richness, which may evidence that the increase in the biomass of fronds did not reflect important differences in the availability of space for attachment.

Concerning the hydroid species, the occurrence of some dominant species which are always more frequent and abundant than the others seems to be common (e.g. KaTo et al. 1961, Boero \& Fresi 1986, Roca et al. 1991). Haddad \& Chiaverini (2000) found that three species of hydroids, Obelia geniculata (Linnaeus, 1758), O. sargassicola and Sertularia distans (Lamouroux, 1816) were responsible for the higher levels of S. stenophylum cover, while the other four species together did not achieve $1 \%$ of algal cover. In our study A. latecarinata, O. sargassicola, D. disticha and $S$. turbinata were usually dominant in algal cover, being present in almost all fronds collected in all sampling periods.

Dominant hydroid species may influence the spatial distribution of other species of hydroids growing on the same alga by means of interspecific competition, inducing a decrease in their colony size and abundance (Kato et al. 1962a, b, 1969). It was not possible, however, to observe the existence of interspecific competition among the dominant and non-dominant species in this study, since no analysis was done on the spatial distribution of the hydroid species on the algal fronds. Despite this, many studies have shown that hydroid larvae may settle at specific places on the algal thallus, as a response to different environmental conditions and continual growth of the algal substrate (Hughes et al. 1991, FRASCHETTI et al. 2006), especially when perennial algae species are considered, such as $S$. cymosum (PAUlA \& Oliveira-Filho 1980). The morphology of the algae, chemical substances produced by it and the period of larval recruitment may also influence the intensity of larval settlement, and consequently, hydroid species abundance (NisHiHIRA 1967, 1968a, b, c). 
In general, epiphytic hydroid studies report the prevalence of species with fixed gonophores (e.g. Boero 1987, FraschetTi et al. 2006), and the same happened in our study. Considering all the species found, only Clytia gracilis (M. Sars, 1851) and Obelia dichotoma (Linnaeus, 1758) produce free medusa, while all the others reproduce by fixed gonophores (CALDER 1991b, 1997, Cornelius 1995a, Migotto 1996). An exception may be the case of Dentitheca bidentata (Jäderholm, 1920), O. sargassicola and Sertularia marginata (Kirchenpauer, 1864), which produce shortlived medusoids (CAlder 1991b, Migotto 1998, Migotto \& MARQUES 1999). The absence of a long-lived medusa stage in the majority of epiphytic hydroid species enables them to persist on a favorable algal substrate, ensuring a suitable substrate for subsequent generations (FraschetTi et al. 2002, Ronowicz et al. 2008). In favorable conditions, these species larvae may settle at the vicinity of their conspecific colonies, and substantially increase their abundance on the alga. Considering the dominant hydroid species, little information exists on their life cycle and reproduction periods. L.P. Andrade (pers. comm.) verified that $A$. latecarinata from São Sebastião, Brazil, have its peak of reproduction during the summer months, the same period of this species highest cover values recorded in the present study. In what concerns $O$. sargassicola, no information on its reproduction periods is available for the study area.

Other species of the fauna associated to Sargassum may also directly or indirectly affect hydroid cover. Studies have shown that macrofaunal larvae and juveniles may be affected by meiofauna, in terms of predation, competition for food or space, by increasing their mortality rates and decreasing successful settling (e.g. DAHMs et al. 2004). Other members of the macrofauna may also affect epiphytic species abundance indirectly, by grazing on macrophytes (STONER et al. 1995). Herbivore grazing pressure greatly affects the macrophyte community structure, reducing parts of the plants frequently occupied by epiphytic hydroids (García-Rubies 1987, Elger et al. 2009). Gammarid amphipods are important meso-herbivores on macroalgal communities, grazing on Sargassum and associated epiphytes (JACobucCi \& LeIte 2008). JACobUCCI \& Leite (2002) observed that the abundance of gammarid amphipods associated with S. cymosum from Lázaro beach was higher during winter (minimum hydroid cover) and lower during summer, which coincides with the period of maximum hydroid algal cover recorded in this study. Their grazing activity on S. cymosum during the period of their maximum abundance (winter) may have contributed to the lower levels of hydroid algal cover recorded in this season.

In what concerns the environmental factors, it is known that in tropical areas species have their peak of abundance during the periods of maximum rainfall, mostly because of the large availability of food, characteristic of this period (e.g. CAmillo et al. 2008). Energetic constraints caused by the seasonal variation of food availability may be responsible for declines on hydroid growth rates and regression of polyps (GILI \& HugHes 1995), be- ing also considered one of the factors behind the occurrence of summer dormancy of some hydroid species on the Mediterranean (Coma \& Ribes 2003). Since no abiotic factors were examined during the sampling of this study, it is difficult to associate the variations on hydroid cover with the changes on nutrient availability with season. It is known, however, that the sediments from Lázaro beach present the highest organic matter content when compared to other sites located at the Fortaleza inlet, in Ubatuba (Negreiros-Fransozo et al. 1991). Studies have shown that this higher organic matter content is responsible for the higher abundance of some benthic organisms in this area (Fransozo et al. 1992, Mantelatto et al. 1995). This may evidence the importance of nutrient availability for benthic species in Lázaro beach, and it may also be true for epiphytic hydroids. It may be considered another important factor affecting hydroids algal cover, especially in tropical epiphytic communities.

Hydroid algal cover changed significantly with time, and this change may be influenced by a variety of biotic and abiotic factors that might be different considering the study area. Therefore, the seasonal effect must be taken into account in any study involving epiphytic hydroid species, since it can determine the composition and abundance of species in a specific time and place.

\section{ACKNOWLEDGMENTS}

The authors would like to thank O.M.P. Oliveira for providing references and helping with species identification. We also thank P.K. Maruyama and T.P. Miranda for their valuable help revising the manuscript, two anonymous referees for comments on the previous version of the manuscript and A.C. Marques and CAPES Pró-Equipamentos for the laboratory equipments used at Universidade de São Paulo.

\section{LITERATURE CITED}

Arillo, A.; G. Bavestrello \& F. Boero. 1989. Circannual cycle and oxygen consumption in Eudendrium glomeratum (Cnidaria, Anthomedusae): studies on a shallow water population. Marine Ecology 10 (4): 289-301. doi: 10.1111/ j.1439-0485.1989.tb00074.x.

Bavestrello, G.; S. Puce; C. Cerrano; E. Zocchi \& N. Boero. 2006. The problem of seasonality of benthic hydroids in temperate waters. Chemistry and Ecology 22: 197-205. doi: 10.1080/ 02757540600670810.

Boero, F. 1987. Evolutionary implications of habitat selection in the hydroids of Posidonia oceania meadowns, p. 251-256. In: J. Boulllon; F. Boero; F. Cicogna \& P.F.S. Cornelius (Eds). Modern Trends in the Systematics, Ecology, and Evolution of Hydroids and Hydromedusae. Clarendon Press, Oxford, XXI+328p.

Boero, F. 1994. Fluctuations and variations in coastal marine environments. Marine Ecology 15 (1): 3-25. doi: 10.1111/ j.1439-0485.1994.tb00038.x. 
Boero, F. \& E. Fresi. 1986. Zonation and evolution of a rocky bottom hydroid community. Marine Ecology 7 (2): 123150. doi: 10.1111/j.1439-0485.1986.tb00152.x.

Boero, F.; L. Chessa, C. Chimenz \& E. Fresi. 1985. The zonation of epiphytic hydroids on the leaves of some Posidonia oceanica (L.) DELILE beds in the Central Mediterranean. Marine Ecology 6 (1): 27-33. doi: 10.1111/j.1439-0485.1985.tb0 0318.x.

Borowitzka, M.A.; R.C. Lethbridge \& L. Charton. 1990. Species richness, spatial distribution and colonisation pattern of algal and invertebrate epiphytes on the seagrass Amphibolis griffithii. Marine Ecology Progress Series 64: 281-291.

Calder, D.R. 1990. Seasonal cycles of activity and inactivity in some hydroids from Virginia and South Carolina, U.S.A. Canadian Journal of Zoology 68 (3): 442-450. doi:10.1139/ z90-065.

Calder, D.R. 1991a. Associations between hydroid species assemblages and substrate types in the mangal at Twin Cays, Belize. Canadian Journal of Zoology 69 (8): 2067-2074. doi: 10.1139/z91-288.

CALDER, D.R. 1991b. Shallow-water hydroids of Bermuda: The Thecate, exclusive of Plumularioidea. Toronto, Life Science Contributions 154, Royal Ontario Museum, IV+107p.

Calder, D.R. 1995. Hydroid assemblages on holopelagic Sargassum from the Sargasso Sea at Bermuda. Bulletin of Marine Science 56 (2): 537-546.

CALDER, D.R. 1997. Shallow-water hydroids of Bermuda: Superfamily Plumularioidea. Toronto, Life Sciences Contributions 161, Royal Ontario Museum, V+86.

Camillo, C.G. Di; G. Bavestrello; L. Valisano \& S. Puce. 2008. Spatial and temporal distribution in a tropical hydroid assemblage. Journal of the Marine Biological Association of the United Kingdom 88 (8): 1589-1599. doi:10.1017/ S0025315408002981

Coma, R. \& M. Ribes. 2003. Seasonal energetic constraints in Mediterranean benthic suspension feeders: effects at different levels of ecological organization. Oikos 101 (1): 205-215. doi: 10.1034/j.1600-0706.2003.12028.

Coma, R.; M. Ribes; J.M. Gili \& M. Zabala. 2000. Seasonality in coastal benthic ecosystems. Trends in Ecology \& Evolution 15 (11): 448-453. doi:10.1016/S0169-5347(00)01970-4.

Cornelius, P.F.S. 1995a. North-West European Thecate Hydroids and their Medusae, p. 1-347. In: R.S.K. Barnes \& J.H. Crothers (Eds). Synopses of the British Fauna New Series. Shrewsbury, Field Studies Council, Part 1, \#50, VII+ 347.

Cornelius, P. F.S. 1995b. North-west European Thecate Hydroids and their Medusae. In: R.S.K. Barnes \& J.H. Crothers (Eds). Synopses of the British Fauna New Series. Shrewsbury, Part 2, \#50, VII+386.

DAHMS, H.U.; T. HARDER \& P.Y. QIAN. 2004. Effect on meiofauna on macrofauna recruitment: settlement inhibition of the polychaete Hydroides elegans by the harpacticoid copepod Tisbe japonica. Journal of Experimental Marine Biology and Ecology 311 (1): 47-61. doi:10.1016/j.jembe.2004.04.016.
Elger, A.; N.J. Willby \& M. Cabello-Martinez. 2009. Invertebrate grazing during the regenerative phase affects the ultimate structure of macrophyte communities. Freshwater Biology 54 (6): 1246-1255. doi: 10.1111/j.1365-2427.2009.02171.

FAUCCI, A. \& F. BoERo. 2000. Structure of an epiphytic hydroid community on Cystoseira at two sites of different wave exposure. Scientia Marina 64 (Supl. 1): 255-264. doi: 10.3989/scimar.2000.64s1255.

Fransozo, A.; M.L. Negreiros-Fransozo; F.L.M. Mantelatto; M.A.A. Pinheiro \& S. SAntos. 1992. Composição e distribuição dos Brachyura (Crustacea, Decapoda) do sublitoral não consolidado na Enseada da Fortaleza, Ubatuba (SP). Revista Brasileira de Biologia 52 (4): 667-675.

Fraschetti, S.; A. Giangrande; A. Terlizzi; M.P. Miglietta; L.D. Tommasa \& F. Boero. 2002. Spatio-temporal variation of hydroids and polychaetes associated with Cystoseira amentacea (Fucales: Phaeophyceae). Marine Biology 140: 949-957. Doi: 10.1007/s00227-001-0770-9.

Fraschetti, S.; A. Terlizzi; S. Bevilacqua \& F. Boero. 2006. The distribution of hydroids (Cnidaria, Hydrozoa) from microto macro-scale: spatial patterns on habitat-forming algae. Journal of Experimental Marine Biology and Ecology 339 (2): 148-158. doi: 10.1016/j.jembe.2006.07.007.

GarCía-Rubies, A. 1987. Distribution of epiphytic hydroids on Posidonia seagrass, p. 143-155. In: J. Boulllon; F. Boero; F. Cicogna \& P.F.S. Cornelius (Eds). Modern Trends in the Systematics, Ecology, and Evolution of Hydroids and Hydromedusae. Clarendon Press, Oxford, XXI+ 328.

García-Rubies, A. 1992. Habitat differentiation among epiphytic hydroids of the seagrass Posidonia oceanica from the Medes Islands (NE Catalonia, Spain), p. 263-267. In: J. BoullLon; F. Boero; F. Cicogna; J.M. Gili \& R.G. Hughes (Eds). Aspects of Hydrozoan Biology. Barcelona, Scientia Marina, Instituto de Ciencias del Mar, IV+193.

GenZANO, G.N. \& G.M. Rodriguez. 1998. Association between hydroid species and their substrates from the intertidal zone of Mar Del Plata (Argentine). Miscelània Zoològica 21 (1): 21-29.

Gili, J. \& R.G. Hughes. 1995. The ecology of marine benthic hydroids. Oceanography and Marine Biology: an annual review 33: 351-426.

Gili, J.M.; J. Murillo \& J. Ros. 1989. The distribution pattern of benthic Cnidarian in the Western Mediterranean. Scientia Marina 53 (1): 19-35.

Gili, J.M.; V. Alvh; R. Coma; C. Orejas; F. Pagès; M. Ribes; M. Zabala; W. Arntz; J. Boulllon; F. Boero \& R.G. Hughes. 1998. The impact of small benthic passive suspension feeders on shallow marine ecosystems: the hydroids as an example. Zoologische Verhandelingen 323: 99-105.

Haddad, M.A. \& A.P. Chiaverini. 2000. Repartição de espaço entre hidróides (Cnidaria, Hydrozoa) epifíticos em Sargassum stenophylum (Phaeophyta, Fucales) de Guaratuba, Paraná. Anais do V Simpósio de Ecossistemas Brasileiros: Conservação 2,p. 101-109. 
HaYward, P.J. 1980. Invertebrate epiphytes of coastal marine algae, p. 761-787. In: J.H. Price; D.E.G. Irvine \& W.F. FARNhAM (Eds).The shore environment. London, The Systematics Association Special Volume, XX+1044.

HeCK, K.L. JR \& G.S. Wetstone. 1977. Habitat complexity and invertebrate species richness and abundance in tropical seagrass meadows. Journal of Biogeography 4: 135-142. doi:10.2307/3038158.

Hughes, R.G. 1986. Differences in the growth, form and life history of Plumularia setacea (Ellis and Solander) (Hydrozoa: Plumulariidae) in two contrasting habitats. Proceedings of the Royal Society of London Biological Sciences 228 (1251): 113-125. doi: 10.1098/rspb.1986.0045.

Hughes, R.G.; S. Johnson \& I.D. SMith. 1991. The growth patterns of some hydroids that are obligate epiphytes of seagrass leaves. Hydrobiologia 216/217: 205-210. doi: 10.1007/ BF00026463.

Jacobucci, G.B. \& F.P.P. Leite. 2002. Distribuição vertical e flutuação sazonal da macrofauna vágil associada a Sargassum cymosum C. Agardh, na praia do Lázaro, Ubatuba, São Paulo, Brasil. Revista Brasileira de Zoologia 19 (Supl. 1): 87100. doi: 10.1590/S0101-81752002000500004.

Jacobucci, G.B. \& F.P.P. Leite. 2008. Effect of temporal variation and size of herbivorous amphipods on consumption levels of Sargassum filipendula (Phaeophyta, Fucales) and their main epiphyte, Hypnea musciformis. Neotropical Biology and Conservation 3 (2): 78-85.

Kato, M.; E. Hirai \& Y. Kakinuma. 1962a. Laboratory experiments on the interespecific relation in the colony formation of some hydrozoan species. Bulletin of the Marine Biological Station of Asamushi 11 (2): 87-89.

Kato, M.; E. Hirai \& Y. Kakinuma. 1969. Coaction among hydrozoan species in the colony formation. Bulletin of the Marine Biological Station of Asamushi 8 (3): 179-181.

Kato, M.; K. Nakamura; E. Hirai \& Y. Kakinuma. 1961. The distribution pattern of Hydrozoa on seaweed with some notes on the so-called coaction among hydrozoan species. Bulletin of the Marine Biological Station of Asamushi 10 (3): 195-202.

Kato, M.; K. Nakamura; E. Hirai \& Y. Kakinuma. 1962b. Interespecific relation in the colony formation among some hydrozoan species. Bulletin of the Marine Biological Station of Asamushi 11 (1): 31-35.

Leite, F.P.P. \& A. TurRa. 2003. Temporal variation in Sargassum biomass, Hypnea epiphytism and associated fauna. Brazilian Archives of Biology and Technology 46 (4): 665-671. doi: 10.1590/S1516-89132003000400021.

Littler, D.S.; M.M. LitTler; K.E. Bucher \& J.N. Norris. 1989. Marine Plants of The Caribbean: a field guide from Florida to Brazil. Washington, D.C., Smithsonian Institution Press, VII+263p.

Llobet, I.; J.M. Gili \& R.G. Hughes. 1991. Horizontal, vertical and seasonal distributions of epiphytic hydrozoa on the alga
Halimeda tuna in the Northwestern Mediterranean Sea. Marine Biology 110 (1): 151-159. doi: 10.1007/BF01313102.

Mantelatto, F.L.M.; A. Fransozo \& M.L. Negreiros-Fransozo. 1995. Distribuição do caranguejo Hepatus pudibundus (Herbst, 1785) (Crustacea, Decapoda, Brachyura) na Enseada da Fortaleza, Ubatuba (SP), Brasil. Boletim do Instituto Oceanográfico 43 (1): 51-61.

MigotTo, A.E. 1996. Benthic shallow-water hydroids (Cnidaria, hydrozoa) of the coast of São Sebastião, Brazil, including a checklist of Brazilian hydroids. Zoologische Verhandelingen 306: 1-125.

Migotto, A.E. 1998. The life cycle of Sertularia marginata Kirchenpauer, 1864 (Cnidaria: Hydrozoa): a medusoidproducing sertulariid. Journal of Natural History 32 (1): 1-12. doi: 10.1080/00222939800770011.

Migotto, A.E. \& A.C. Marques. 1999. Redescription of Dentitheca bidentata (Cnidaria: Hydrozoa, Plumulariidae), with notes on its life cycle. Journal of Natural History 33 (7): 949 960. doi: 10.1080/002229399300029.

Migotto, A.E.; A.C. Marques; A.C. Morandini \& F.L. Silveira. 2002. Checklist of the Cnidaria Medusozoa of Brazil. Biota Neotropica 2 (1):1-31.

Negreiros-Fransozo, M.L.; A. Fransozo; M.A.A. Pinheiro; F.L.M. Mantelatto \& S. SAntos. 1991. Caracterização física e química da Enseada de Fortaleza, Ubatuba, SP. Revista Brasileira de Geociências 21 (2): 114-120.

Niermann, U. 1986. Distribution of Sargassum natans and some of its epibionts in the Sargasso Sea. Helgoland Marine Research 40 (41): 343-353. doi: 10.1007/BF01983817.

Nishinira, M. 1965. The association between Hydrozoa and their attachment substrata with special reference to algal substrata. Bulletin of the Marine Biological Station of Asamushi 12 (2-3): 75-92.

Nishinira, M. 1967. Observations on the selection of algal substrata by hydrozoan larvae, Sertularella miurensis in nature. Bulletin of the Marine Biological Association of Asamushi 13 (1): 35-48.

NishiniRA, M. 1968a. Experiments on the algal selection by the larvae of Coryne uchidai Stechow (Hydrozoa). Bulletin of the Marine Biological Association of Asamushi 13 (2): 83-89.

Nishinira, M. 1968b. Brief experiments on the effect of algal extracts in promoting the settlement of the larvae of Coryne uchidai Stechow (Hydrozoa). Bulletin of the Marine Biological Association of Asamushi 13 (2): 91-101.

Nishinira, M. 1968c. Dynamics of natural populations of epiphytic hydrozoa with special reference to Sertularella miurensis Stechow. Bulletin of the Marine Biological Association of Asamushi 13 (2): 103-124.

NishiHIRA, M. 1971. Colonization pattern of hydrozoa on several species of Sargassum. Bulletin of the Marine Biological Station of Asamushi 14 (2): 99-108.

Oliveira, O.M.P. \& A.C. Marques. 2007. Epiphytic hydroids 
(Hydrozoa: Anthoathecata and Leptothecata) of the World. Check List 3 (1): 21-38.

Oliveira, O.M.P.; A.C. Marques \& A.E. Migotto. 2006. Chave de identificação dos hidrozoários (Cnidaria, Hydrozoa) epifíticos do canal de São Sebastião (SE, Brasil). Biota Neotropica 6 (2): 2-18.

Paula, E.J. \& E.C. Oliveira-Filho. 1980. Aspectos fenológicos de duas populações de Sargassum cymosum (Phaeophyta Fucales) do litoral de São Paulo, Brasil. Boletim de Botânica 8: 21-39.

Roca, I.; I. Moreno. \& R. Barceló. 1991. Distribución espacial y temporal de los hidroideos de Posidonia oceania (L.) Delile em uma pradera del Illot del Sec (Bahía de Palma, Baleares). Boletín del Instituto Español de Oceanografía 7 (1): $67-$ 74.

Ronowicz, M.; M. Wlodarska-Kowalczuk \& P. Kuklinski. 2008. Factors influencing hydroids (Cnidaria: Hydrozoa) biodiversity and distribution in Artic kelp forest. Journal of the Marine Biological Association of the United Kingdom 88 (8): 1567-1575. doi: 10.1017/S0025315408001495.

RYLAND, J.S. 1974. Observations on some epibionts of Gulf-Weed, Sargassum natans (L.) Meyen. Journal of Experimental
Marine Biology and Ecology 14 (1): 17-25. doi:10.1016/ 0022-0981(74)90034-3.

SEED, R. \& R.J. O'CONNOR. 1981. Community organization in marine algal epifaunas. Annual Review of Ecology and Systematics 12: 49-74. doi: 10.1146/annurev.es.12.110181.000405.

Stoner, A.W. 1980. The role of seagrass biomass in the organization of benthic macrofaunal assemblages. Bulletin of Marine Science 30 (3): 537-551.

Stoner, A.W.; M. Ray \& J.M. Waite. 1995. Effects of a large herbivorous gastropod on macrofauna communities in tropical seagrass meadows. Marine Ecology Progress Series 121: 125-137. doi: 10.3354/meps121125.

Széchy, M.T.M. \& E.J. Paula. 1997. Macroalgas epífitas em Sargassum (Phaeophyta - Fucales) do litoral dos estados do Rio de Janeiro e São Paulo, Brasil. Leandra 12: 1-10.

Watson, J.E. 1992. The hydroid community of Amphibolis seagrass in south-eastern and south-western Australia, p. 217-227. In: J. Boulllon; F. Boero; F. Cicogna; J.M. Gili \& R.G. Hughes (Eds). Aspects of Hydrozoan Biology. Barcelona, Scientia Marina, Instituto de Ciencias del Mar, IV+193.

ZAR, J.H. 1996. Biostatistical Analysis. New Jersey, PrenticeHall International, Inc., X+918p.

Submitted: 07.IV.2010; Accepted: 08.X.2010.

Editorial responsibility: Rosana M. da Rocha 